\title{
Axotomy Upregulates the Anterograde Transport and Expression of Brain-Derived Neurotrophic Factor by Sensory Neurons
}

\author{
James R. Tonra, Rory Curtis, Vivien Wong, Kenneth D. Cliffer, John S. Park, Andrew Timmes, Trang Nguyen, \\ Ronald M. Lindsay, Ann Acheson, and Peter S. DiStefano
}

Regeneron Pharmaceuticals, Inc., Tarrytown, New York 10591

In addition to the known retrograde transport of neurotrophins, it is now evident that endogenous brain-derived neurotrophic factor (BDNF) is transported in the anterograde direction in peripheral and central neurons. We used a double-ligation procedure that distinguishes between anterograde and retrograde flow to quantify the anterograde transport of endogenous neurotrophins and neuropeptides in the peripheral nervous system before and after axotomy. BDNF accumulation proximal to the ligation (anterograde transport) was twice that distal to the ligation (retrograde direction). Anterograde transport of nerve growth factor and neurotrophin-3 was not evident. Furthermore, BDNF anterograde transport increased 3.5-fold within 24 hr after sciatic nerve injury or dorsal rhizotomy. Anterograde transport of substance $P$ and calcitonin gene-related peptide decreased after peripheral nerve lesion, demonstrating that there was no generalized increase in anterograde transport. To determine the source of the anterogradely transported BDNF, we performed in situ hybridization in a variety of tissues before and after axotomy. Expression of BDNF mRNA in proximal nerve segments did not change with treatment, showing that the increased accumulation of BDNF was not a result of increased local synthesis. BDNF mRNA and protein were expressed by dorsal root ganglion sensory neurons but not by motor neurons. BDNF mRNA expression was increased $1 \mathrm{~d}$ after nerve injury, and BDNF protein was also increased twofold to threefold, suggesting that sensory neurons are the major contributing source of the increased BDNF traffic in the sciatic nerve. Our results suggest that increased anterogradely transported BDNF plays a role in the early neuronal response to peripheral nerve injury at sites distal to the cell body.

Key words: anterograde transport; retrograde transport; neurotrophin; BDNF; sciatic nerve; dorsal root ganglion
The neurotrophins nerve growth factor (NGF), brain-derived neurotrophic factor (BDNF), neurotrophin-3 (NT-3), and NT-4 are produced by neuronal target tissues and regulate the survival and normal maintenance of neurons (for review, see Barbacid, 1994; Snider, 1994). The uptake of neurotrophins into axons by high-affinity receptors is followed by retrograde transport to the cell bodies of responsive neurons (DiStefano et al., 1992; Curtis et al., 1995). Although it is generally accepted that retrograde transport is critical to neurotrophin function, the exact mechanism of action remains unknown (Curis and DiStefano, 1994). The expression of NT-3 and BDNF in sensory neurons of the dorsal root ganglion (DRG) suggests that the neurotrophins serve roles other than conventional target-derived retrograde signaling factors (Ernfors et al., 1990; Schecterson and Bothwell, 1992; Wetmore and Olson, 1995). The possibility of autocrine or paracrine roles within the ganglion is supported by the observation that DRG neurons in tissue culture produce BDNF that is required for their own survival (Acheson et al., 1995). The production of BDNF by sensory neurons also raises the possibility that the neurotrophins are anterogradely transported and may influence target tissues or

Received Dec. 22, 1997; revised Feb. 23, 1998; accepted March 17, 1998.

We are grateful to Karen Garcia, Elizabeth Zlotchenko, and Carl Jackson for their excellent technical assistance and to Evan Burrows and Claudia Murphy for photographic assistance. We thank Dr. Eugene M. Johnson Jr, Dr. Lorne M. Mendell, and Dr. J. Kessler for antibodies and Dr. Peter C. Maisonpierre for the BDNF mRNA probe. We also thank Dr. Jocelyn Holash and Dr. Sue Bodine for their helpful discussion of the results.

Correspondence should be addressed to Dr. James R. Tonra, Regeneron Pharmaceuticals, Inc., 777 Old Saw Mill River Road, Tarrytown, NY 10591.

Drs. Curtis, Lindsay, and DiStefano, and T. Nguyen's present address: Millennium Pharmaceuticals, Inc., 640 Memorial Drive, Cambridge, MA 02139-4815.

Copyright (ㄷ) 1998 Society for Neuroscience $0270-6474 / 98 / 184374-10 \$ 05.00 / 0$ glial cells. Trafficking of neurotrophins to sites distal to the cell body would suggest new mechanisms of neurotrophin action.

There is mounting evidence for anterograde axonal transport of BDNF. Exogenous ${ }^{125}$ I-labeled BDNF is anterogradely transported by specific nuclei in the avian CNS (von Bartheld et al., 1996; Johnson et al., 1997). Anterograde transport of endogenous $\mathrm{BDNF}$ in the rat CNS is suggested by the presence of BDNF immunoreactivity in brain regions devoid of BDNF mRNA and by the abolition of BDNF in these regions by deafferentation (Altar et al., 1997; Conner et al., 1997). In the peripheral nervous system, interruption of axonal transport by ligation of the sciatic nerve or crush of the dorsal root causes accumulation of BDNF immunoreactivity proximal to the injuries, supporting both peripheral and central anterograde transport by DRG neurons (Zhou and Rush, 1996; Michael et al., 1997). The potential sources of BDNF accumulation in sciatic nerve are DRG sensory neurons, target tissues, or Schwann cells within the nerve, all of which can express BDNF under certain circumstances (Ernfors et al., 1990; Meyer et al., 1992; Schecterson and Bothwell, 1992; Henderson et al., 1993).

In this study, we have used immunohistochemistry and a sensitive ELISA to localize and quantify BDNF anterograde transport in sciatic nerve. In contrast to BDNF, we find no evidence for anterograde transport of NGF or NT-3. We show by in situ hybridization that the primary site of BDNF synthesis is DRG sensory neurons. Furthermore, we demonstrate that the anterograde transport of BDNF is rapidly upregulated when the peripheral nerve or dorsal roots are damaged, and this correlates with increased expression of BDNF by sensory neurons. The increased anterograde transport of BDNF after axonal injury implicates 
this mode of neurotrophin action in the neuronal response to peripheral nerve damage and suggests several novel functions for this member of the neurotrophin family.

\section{MATERIALS AND METHODS}

Surgical procedures. Male Sprague Dawley rats (250-400 gm) were obtained from Zivic Miller (Zelienople, PA), housed two per cage, and given food and water ad libitum. Except where otherwise noted, all rats were anesthetized with ketamine $(50 \mathrm{mg} / \mathrm{kg})$ and xylazine $(10 \mathrm{mg} / \mathrm{kg})$. All animal use in this study was conducted in compliance with approved institutional animal care and use protocols and according to National Institutes of Health guidelines (Guide for the Care and Use of Laboratory Animals, National Institutes of Health publication 86-23, 1985).

To axotomize peripheral axonal processes of sensory and motor neurons, the sciatic nerve was crushed or cut at the level of the knee; either the right sciatic nerve was crushed twice for $10 \mathrm{sec}$ with number 5 fine forceps, or a $5 \mathrm{~mm}$ segment was resected. Sham surgeries only exposed the nerve. Dorsal rhizotomy was performed to damage the central axonal processes of sensory neurons. L4 and L5 roots and DRGs were the focus, because $97 \%$ of DRG neurons projecting into the sciatic nerve in the rat are located in the L4 and L5 DRG (Swett et al., 1991). Briefly, rats were anesthetized with chloral hydrate $(170 \mathrm{mg} / \mathrm{kg})$ and pentobarbital (35 $\mathrm{mg} / \mathrm{kg}$ ), and a laminectomy was performed at the level of the L2 DRG to expose the passing roots on the right side. After opening the dura, the roots were cut and separated with gel foam. At the time of killing it was verified that the L4 and L5 dorsal roots were cut without damage to the ventral roots. Sham surgeries only exposed the dura. After all surgeries, the muscle layers were sutured, and the skin was closed with surgical staples.

To visualize and quantify anterograde and retrograde transport of endogenous neurotrophins and neuropeptides, we performed a doubleligation procedure that has been used previously to examine axonal transport of acetylcholinesterase, neurotransmitters, and neurotrophins in the sciatic nerve (Ranish and Ochs, 1972; Ben-Jonathan et al., 1978; Johnson et al., 1987; Zhou and Rush, 1996). Ligations consisted of two 4-0 silk ligatures tied tightly around the sciatic nerve $0.5 \mathrm{~cm}$ apart, $\sim 1$ $\mathrm{cm}$ distal to the tendon of the obturator internus muscle. Eighteen to 20 $\mathrm{hr}$ later, the ligated nerve was removed for immunostaining or biochemical analysis as described below. We used the double-ligation technique for the following reasons: (1) it interrupts axonal flow, facilitating visualization and quantification of transported substances; (2) it provides clear separation of proximal and distal segments, demonstrating retrograde or anterograde transport of substances by accumulation in these segments; (3) accumulation on the proximal side provides evidence for anterograde transport, whereas accumulation on the distal side indicates retrograde transport; and (4) the middle segment provides information about local synthesis as well as accumulation after placement of the ligature. Although small amounts of a substance in transit within the middle segment may accumulate at the ligations, local synthesis is suggested by uniform distribution throughout the middle segment.

${ }^{125}$ I-labeled BDNF was used to evaluate uptake and anterograde or retrograde transport of BDNF from within the sciatic nerve. ${ }^{125}$ I-BDNF was prepared and formulated according to DiStefano et al. (1992). Twenty-two nanograms of ${ }^{125} \mathrm{I}-\mathrm{BDNF}$ in $0.5 \mu \mathrm{l}$ were injected $14-16 \mathrm{~mm}$ proximal or distal to a single ligature placed on the sciatic nerve under ketamine and xylazine anesthesia. Twenty hours later the nerve between the injection site and ligation was divided into $2 \mathrm{~mm}$ segments, and the ${ }^{125}$ I-BDNF content was quantified by gamma counting.

Immunohistochemistry. Animals were anesthetized and perfused transcardially with ice-cold heparinized saline followed by ice-cold $2 \%$ paraformaldehyde and $15 \%$ picric acid in $0.1 \mathrm{M}$ phosphate buffer, $\mathrm{pH}$ 6.9. Ligatures were removed, and the nerves were equilibrated at $4^{\circ} \mathrm{C}$ for at least $48 \mathrm{hr}$ in $25 \%$ sucrose and $0.1 \mathrm{M}$ phosphate buffer with $0.008 \%$ sodium azide. Frozen sections were cut at $10 \mu \mathrm{m}$ on a cryostat, mounted on slides, and incubated overnight at $4{ }^{\circ} \mathrm{C}$ with various antibodies diluted in $0.1 \mathrm{M}$ phosphate buffer and $0.3 \%$ Triton X-100. A specific goat anti-NGF antiserum was a gift from Dr. E. M. Johnson Jr. (Washington University, St. Louis, MO) (Anderson et al., 1995). A rabbit polyclonal antibody against BDNF was provided by Amgen, Inc. (Thousand Oaks, CA). This antibody is specific for BDNF because it recognizes BDNF but not the other neurotrophins by ELISA (Radka et al., 1996). Furthermore, BDNF immunoreactivity is absent in tissues from BDNF-null mice, as shown by immunohistochemistry and ELISA (Bianchi et al., 1996; Radka et al., 1996; Conner et al., 1997). Rabbit polyclonal antisera against substance $\mathrm{P}$ (SP; Incstar, Stillwater, MN) or calcitonin generelated peptide (CGRP; Zeneca, Macclesfield, UK) were gifts from Dr. Lorne M. Mendell (State University of New York, Stony Brook, NY). Staining was visualized with biotinylated rabbit anti-goat IgG (diluted 1:500) or biotinylated goat anti-rabbit $\operatorname{IgG}$ (diluted 1:200) and the ABC Elite kit for NGF and Standard kit for BONF, CGRP, and SP (Vector, Burlingame, CA), using 3,3'-diaminobenzidine (Sigma, St. Louis, MO) as the chromogen.

In situ hybridization. Plasmid containing full-length rat BDNF cDNA (Maisonpierre et al., 1991) was linearized with either EcoRI for synthesis of antisense BDNF probes using T3 polymerase or KpnI for synthesis of sense BDNF probes using T7 polymerase. ${ }^{35} \mathrm{~S}$-UTP-labeled probes were produced with a Stratagene (La Jolla, CA) RNA transcription Kit. Ten micrometer frozen sections of DRG, spinal cord, and ligated nerve were fixed with $4 \%$ paraformaldehyde for $10 \mathrm{~min}$, acetylated, and hybridized as described (Friedman et al., 1992). Slides were dipped in NTB-2 autoradiographic emulsion (Kodak, Rochester, NY) and exposed at $4{ }^{\circ} \mathrm{C}$ for 3-10 d.

ELISA and radioimmunoassay. Ligatures were removed, and the nerves were cut into proximal, middle, and distal segments $\sim 5 \mathrm{~mm}$ long. DRGs were dissected free of the nerve and roots. The tissues were weighed and frozen on dry ice. Before assay, tissues were homogenized using a rotating Teflon pestle $(1800 \mathrm{rpm})$ for $20 \mathrm{sec}$. In some experiments, the results are expressed relative to tissue mass. In other experiments, notably the measurement of neurotrophins and neuropeptides before and after axotomy (see Fig. 3), protein assay was performed on the nerve segments (Pierce, Rockford, IL), and the results are expressed as nanograms per milligram of protein.

NGF, BDNF, and NT-3 were quantified in tissue extracts by two-site ELISA. The NGF ELISA was performed with a commercially available kit using the monoclonal antibody 27/21 (Boehringer Mannheim, Mannheim, Germany). For the BDNF and NT-3 ELISAs, tissues were homogenized and prepared as described, and the BDNF levels were determined using a monoclonal antibody for capture and a biotinylated polyclonal reporter antibody (Radka et al., 1996). NT-3 levels were determined using a two-site ELISA that used different capture and reporter monoclonal antibodies. Monoclonal antibodies were generated against recombinant human NT-3 by conventional techniques. The linear ranges of the ELISAs were BDNF, $78 \mathrm{pg} / \mathrm{ml}-10 \mathrm{ng} / \mathrm{ml}$; NT-3, $78 \mathrm{pg} / \mathrm{ml}-20 \mathrm{ng} / \mathrm{ml}$; and NGF, $0.1 \mathrm{pg} / \mathrm{ml}-11 \mathrm{ng} / \mathrm{ml}$. The antibodies used in these ELISAs were specific for the individual neurotrophins and did not cross-react with other neurotrophin family members at up to 100 times the maximal concentration used for the standard curve (Radka et al., 1996; A. Acheson, unpublished observations).

SP and CGRP radioimmunoassays were performed as described (Wong and Kessler, 1987), using rabbit anti-SP antiserum (a gift from Dr. J. Kessler, Albert Einstein College of Medicine, Bronx, NY) or commercially available kits for CGRP (Peninsula Laboratories Inc., Belmont, CA).

Data analysis. Differences in means were tested using ANOVA with Fisher's protected least significant difference as a post hoc test; $p<0.05$ was considered statistically significant.

\section{RESULTS}

\section{Retrograde but not anterograde transport of NGF}

We have characterized previously the retrograde transport of exogenous ${ }^{125}$ I-labeled neurotrophins to sensory and motor neurons and the regulation of retrograde transport by neuronal injury (DiStefano et al., 1992; DiStefano and Curtis, 1994; Curtis et al., 1995). To examine the transport of endogenous neurotrophins in the retrograde and/or anterograde direction, we used a doubleligation technique. Accumulation of a substance on the proximal (cell body) side provides evidence for anterograde transport from neurons in the spinal cord or DRG whereas accumulation on the distal (peripheral) side of the double ligature supports retrograde transport. To validate this approach, we examined NGF accumulation by immunohistochemistry and ELISA 18-20 hr after placement of the double ligation. In accordance with previous studies (Palmatier et al., 1984; Korsching and Thoenen, 1985), NGF immunoreactivity was visible on the distal side of the distal ligature and to a lesser extent on the distal side of the proximal 

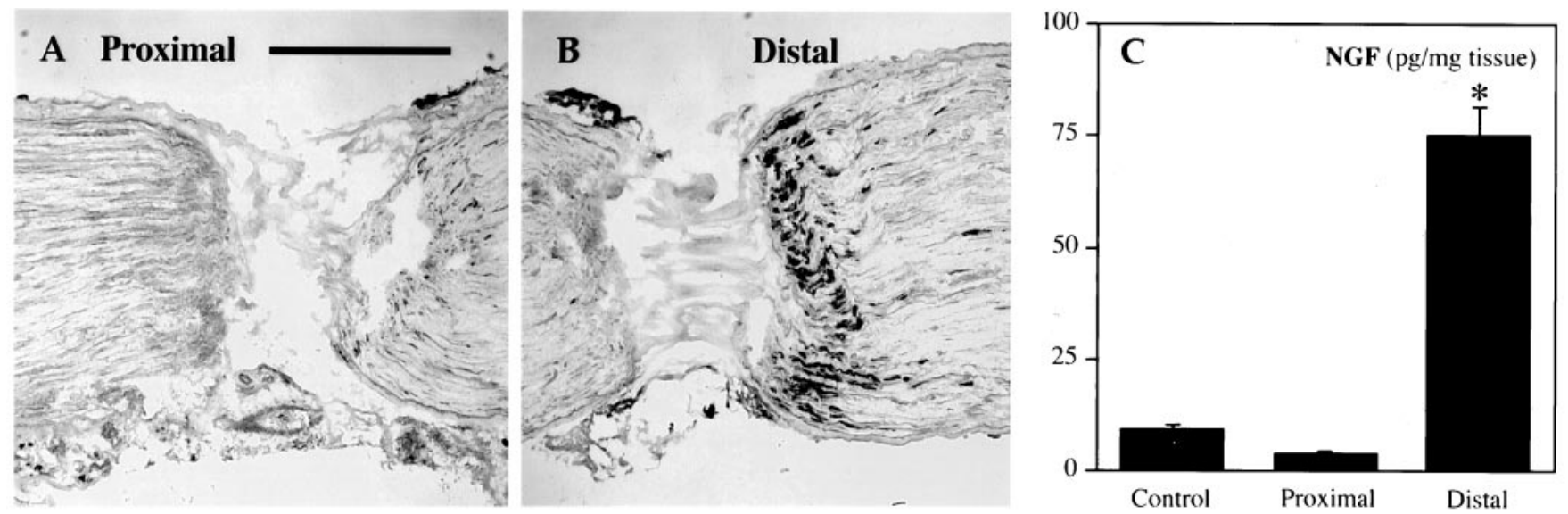

Figure 1. Endogenous NGF is transported retrogradely but not in the anterograde direction. $A, B$, Immunohistochemical staining of NGF accumulation over 18-20 hr proximal $(A)$ and distal $(B)$ to a double ligation. The middle segment of the double ligation is shown in $A$, right, and $B$, left. $C$, NGF levels in untreated sciatic nerve (control) and in segments proximal or distal to an $18-20 \mathrm{hr}$ double ligation. Values represent the mean \pm SEM. ${ }^{*} p<0.01 \mathrm{versus}$ control. Scale bar, $0.5 \mathrm{~mm}$.

ligature (Fig. 1A,B); NGF retrograde transport but not anterograde transport was verified by quantitative NGF ELISA (Fig. 1C).

\section{Anterograde transport of BDNF is increased by neuronal injury}

We next examined the transport of endogenous BDNF in the sciatic nerve using a BDNF-specific antibody (see Materials and Methods). When the sciatic nerve was removed immediately after placement of a double ligation, BDNF immunoreactivity was not visualized on either side of the ligature (Fig. $2 A-C$ ). However, BDNF was localized on the proximal and distal sides of a double ligation after $18-20 \mathrm{hr}$ (Fig. 2D-F). BDNF was particularly intense on the proximal side, suggesting a predominance of anterograde transport. The accumulation of BDNF proximal to the ligature resembled the distribution of neuropeptides SP and CGRP (Fig. 2M,N), which are known to be anterogradely transported in the axons of DRG neurons (Kruger et al., 1985; IshidaYamamoto et al., 1989).

We have reported previously that retrograde transport of exogenous neurotrophins is modulated by neuronal injury (DiStefano and Curtis, 1994). To examine the effects of injury on anterograde and retrograde transport of endogenous BDNF, a double ligation was placed on the sciatic nerve proximal to a crush injury of the nerve made $1 \mathrm{~d}$ earlier or $1 \mathrm{~d}$ after cutting L4 and L5 dorsal roots. The accumulation of BDNF proximal to the ligation over the standard 18-20 hr period increased dramatically both after sciatic crush (Fig. 2G-I) and after rhizotomy (Fig. 2J-L). Taken together, these immunohistochemical results support both the retrograde and anterograde transport of endogenous BDNF in the sciatic nerve, as reported previously (Zhou and Rush, 1996), and show that anterograde transport of BDNF is increased after damage to either the dorsal roots or sciatic nerve.

The immunohistochemical results were corroborated using a sensitive two-site ELISA for BDNF in the different nerve segments (Fig. 3A). Baseline BDNF content was measured in nerve segments removed immediately after double ligation to account for nonspecific effects of nerve manipulation. BDNF levels were 30 times greater than baseline levels in the proximal nerve segment and 13 times greater in the distal nerve segment 18-20 hr after double ligation. In agreement with the immunohistochemistry, BDNF accumulation proximal to the ligations in these control nerves was significantly greater than in the distal nerve $(p<0.0001)$, showing that the anterograde transport of BDNF is greater than retrograde transport. BDNF levels in the segment of nerve between the two ligations (middle) were not significantly different from baseline, indicating a lack of local BDNF production. The local BDNF concentration in the proximal segment $\left(\sim 2 \times 10^{-9} \mathrm{M}\right)$ can be calculated from the total amount of BDNF that builds up at the ligature $(\sim 800 \mathrm{pg})$ and the approximate volume of the tissue (16 $\mu \mathrm{l}, 5 \mathrm{~mm}$ nerve segment assuming a diameter of $2 \mathrm{~mm}$ ).

When the double ligation was placed on the sciatic nerve $1 \mathrm{~d}$ after crushing the nerve distal to the ligation site or cutting the L4 and L5 dorsal roots, the accumulation of BDNF proximal to the ligations was increased by $\sim 3.5$-fold compared with control values (Figs. $3 A, 4$ ). This did not reflect an overall increase in protein in the nerve, because identical results were obtained when BDNF levels were expressed relative to the tissue weight or protein content. Nerve crush and rhizotomy did not change the BDNF levels in the middle segment, indicating a lack of local BDNF synthesis $1 \mathrm{~d}$ after neuronal injury. Transport in the retrograde direction was not increased $1 \mathrm{~d}$ after rhizotomy. It is difficult to assess the effects of nerve crush on retrograde transport with this paradigm, because nerve injury distal to the ligatures separated the nerve from potential sites of BDNF acquisition from the peripheral target tissues (Schecterson and Bothwell, 1992; Henderson et al., 1993).

Baseline levels of NT-3 were higher than BDNF in all nerve segments (Fig. 3B), consistent with NT-3 mRNA expression in the normal nerve (Funakoshi et al., 1993). NT-3 levels in the proximal, middle, and distal nerve segments were greater than baseline values $18-20 \mathrm{hr}$ after double ligation. In contrast to BDNF, there were no significant differences between segments, indicating that NT-3 levels were probably increased by local synthesis, although it remains possible that some NT-3 had accumulated by retrograde or anterograde transport. NT-3 levels in the nerve segments were also not significantly altered by either previous nerve crush or rhizotomy. Therefore, the anterograde and retrograde transport of BDNF and the regulation of BDNF anterograde transport by nerve injury set this neurotrophin apart from NT-3 and NGF.

To test whether the increase in BDNF anterograde transport was linked to a general increase in anterograde transport, we 
Proximal
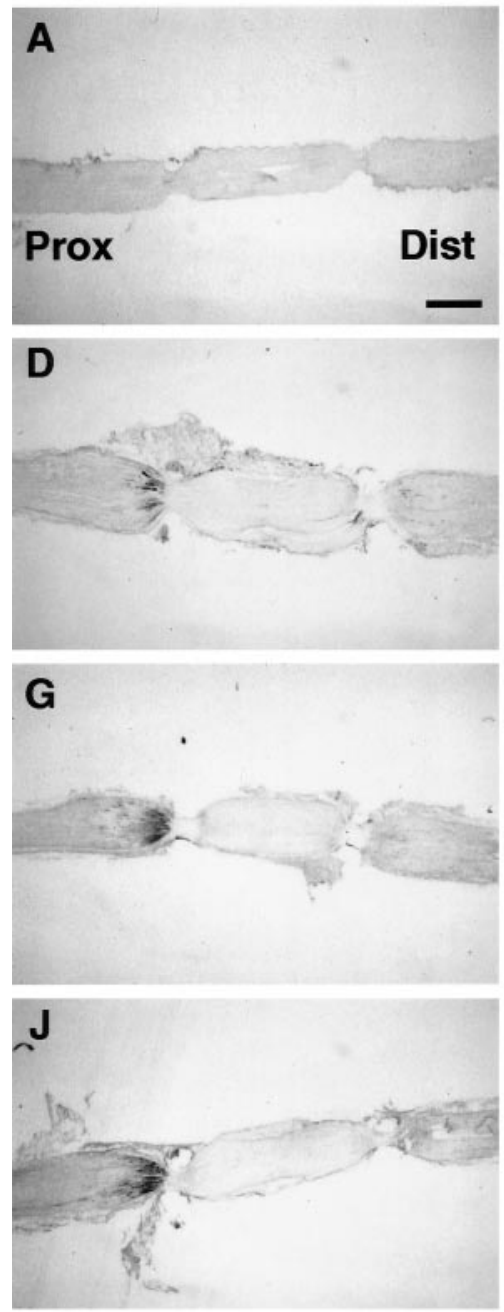
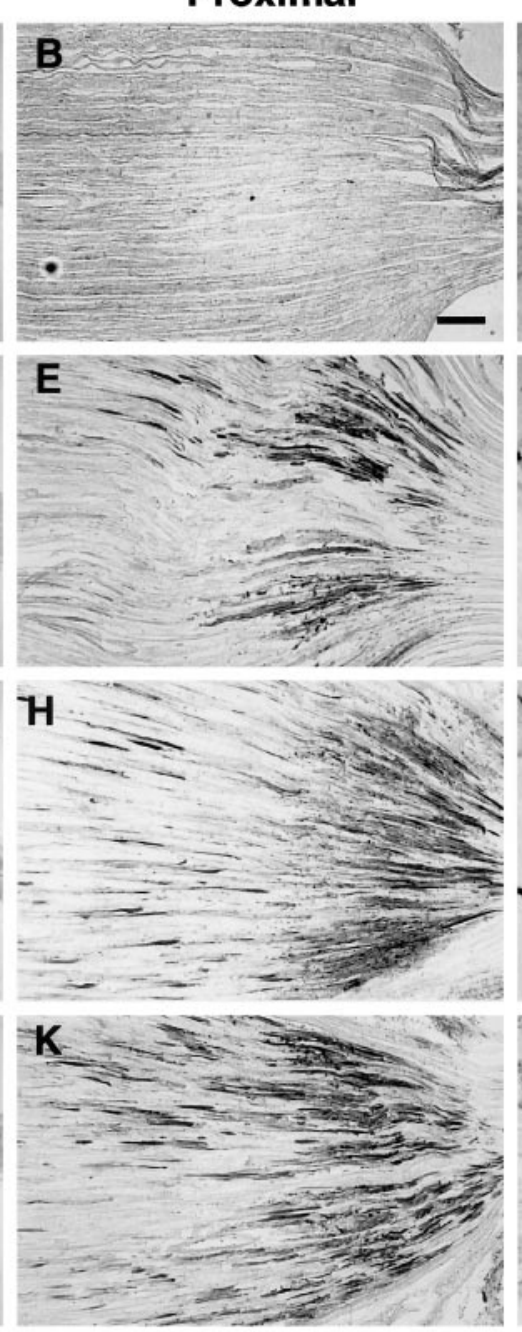

Proximal
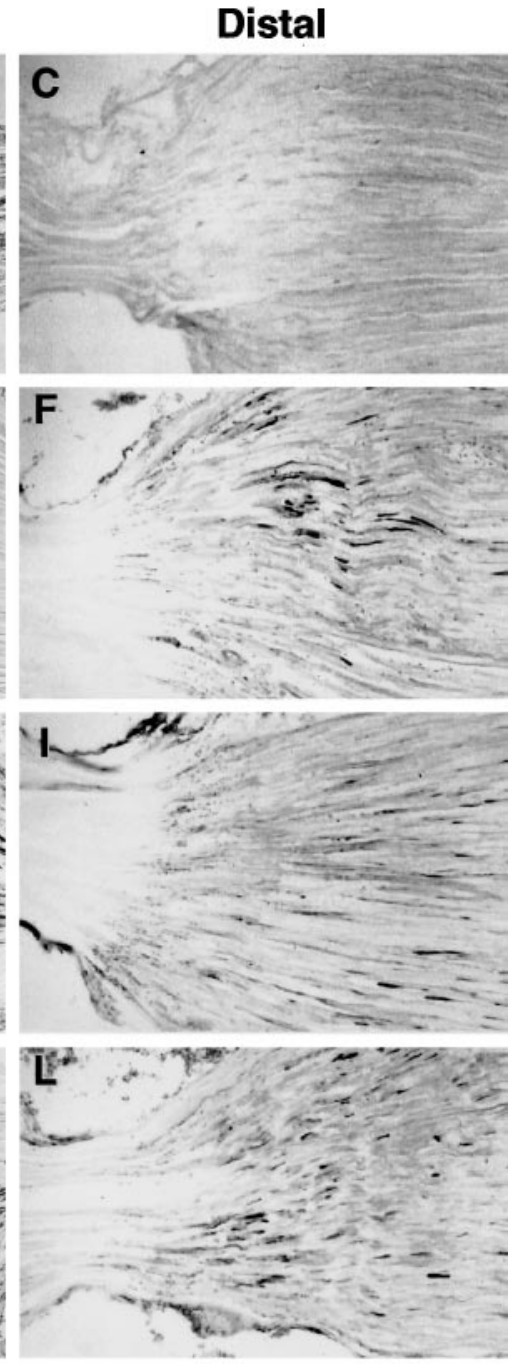
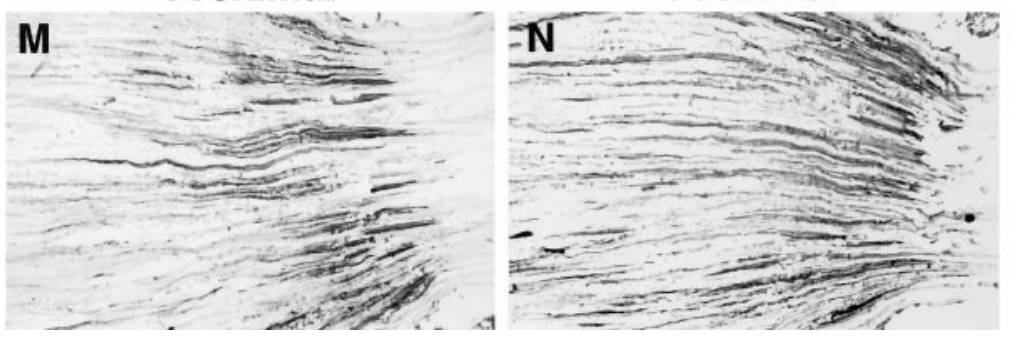

Figure 2. Immunohistochemical staining of endogenous BDNF $(A-L)$ in rat sciatic nerve proximal and distal to a double ligation. In the low power micrographs $(A, D, G, J)$, the proximal (central) side is left and the distal (peripheral) side is right. Higher-magnification photomicrographs show proximal nerve segments $(B, E, H, K)$ illustrating anterograde transport or distal segments $(C, F, I, L)$ showing retrograde transport. $A-C$, Nerve removed immediately after ligation; $D-F, 18-20 \mathrm{hr}$ after ligation in untreated rats; $G-I, 18-20 \mathrm{hr}$ after ligation in rats whose sciatic nerve was crushed $1 \mathrm{~d}$ earlier; $J-L, 18-20 \mathrm{hr}$ after ligation in rats $1 \mathrm{~d}$ after rhizotomy. Immunohistochemical staining of SP $(M)$ and CGRP $(N)$ in proximal segment 18-20 hr after ligation in untreated rats is shown. Scale bars: $A$ (for $A, D, G, J$ ), $1 \mathrm{~mm} ; B$ (for all others), $100 \mu \mathrm{m}$.

quantified the accumulation of SP and CGRP at the double ligation in normal animals and after nerve crush. SP and CGRP both accumulated at the proximal side of an 18-20 hr double ligation but, unlike BDNF, the accumulation was decreased $1 \mathrm{~d}$ after crushing the sciatic nerve (Fig. $3 C, D$ ). The decreased accumulation at the ligation was not associated with a change in the total protein content in the DRG $(p>0.7$ for SP and CGRP, one-way ANOVA). These results are in agreement with the reported lack of changes in the level of SP (Jessell et al., 1979) and
CGRP (Dumoulin et al., 1991) in rat DRG $1 \mathrm{~d}$ after sciatic nerve transection. Therefore, neuronal injury does not cause a general increase in anterograde transport of axonally transported proteins.

To examine the time course of the effect of axonal injury on BDNF anterograde transport, double ligatures were made 1-3 d after crushing the sciatic nerve or cutting the dorsal roots. Whereas BDNF anterograde transport was elevated $1 \mathrm{~d}$ after nerve crush, the accumulation of BDNF proximal to the ligature 

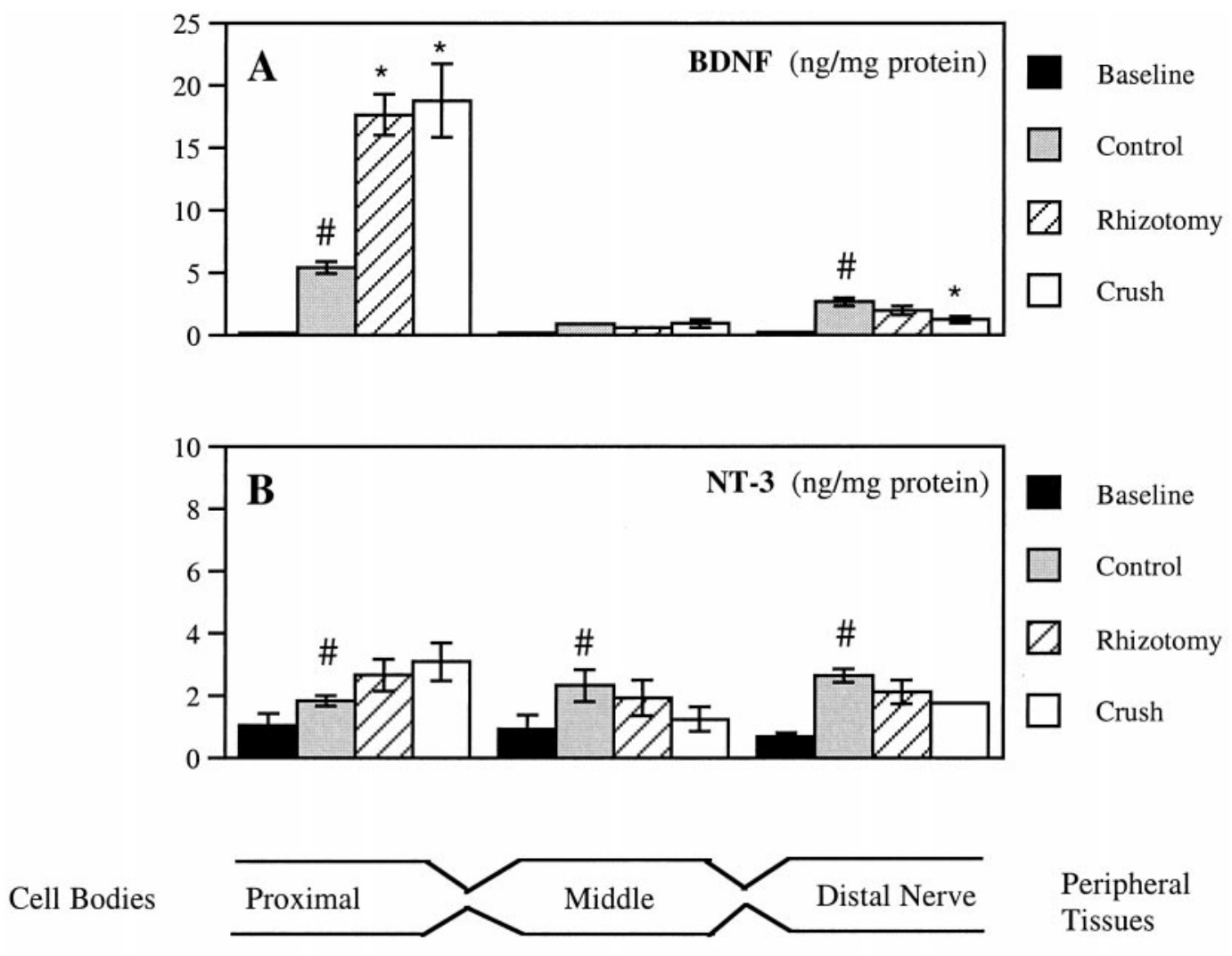

Double Ligation
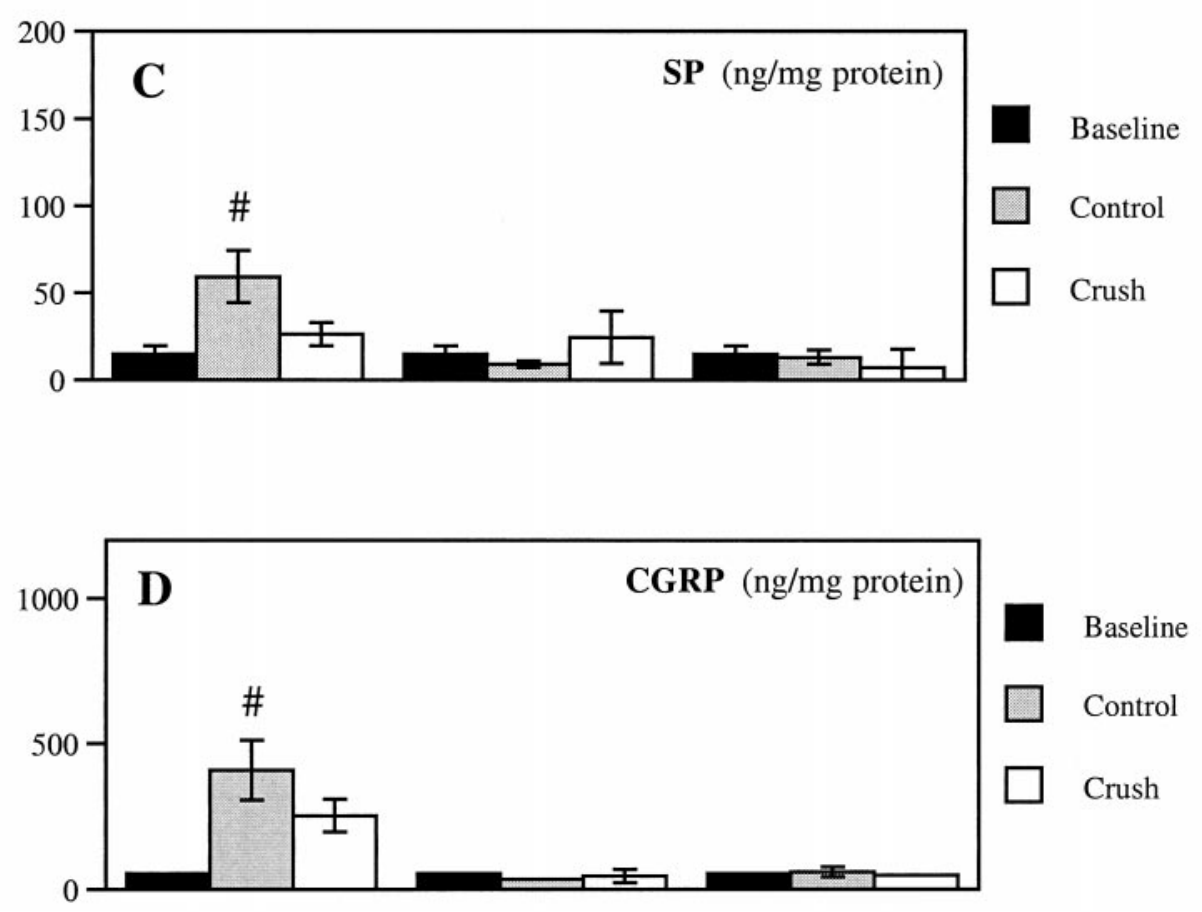

Figure 3. Quantification of endogenous neurotrophin and neuropeptide levels in proximal, middle, and distal segments of rat sciatic nerve subsequent to a double ligation. The diagram illustrates the nerve segments removed from the ligated nerve. $A$, BDNF; $B, \mathrm{NT}-3 ; C$, SP; $D$, CGRP. Nerve was removed immediately after ligation (Baseline), 18-20 hr after ligation in untreated rats (Control), or 18-20 hr after ligation after rhizotomy (Rhizotomy) or sciatic crush (Crush) $1 \mathrm{~d}$ previously. Values represent the mean \pm SEM of five or six rats for BDNF and NT-3 and three animals for SP and CGRP. Note the different scales for each graph. ${ }^{*} p<0.01$ versus control; ${ }^{\#} p<0.05$ versus baseline. 


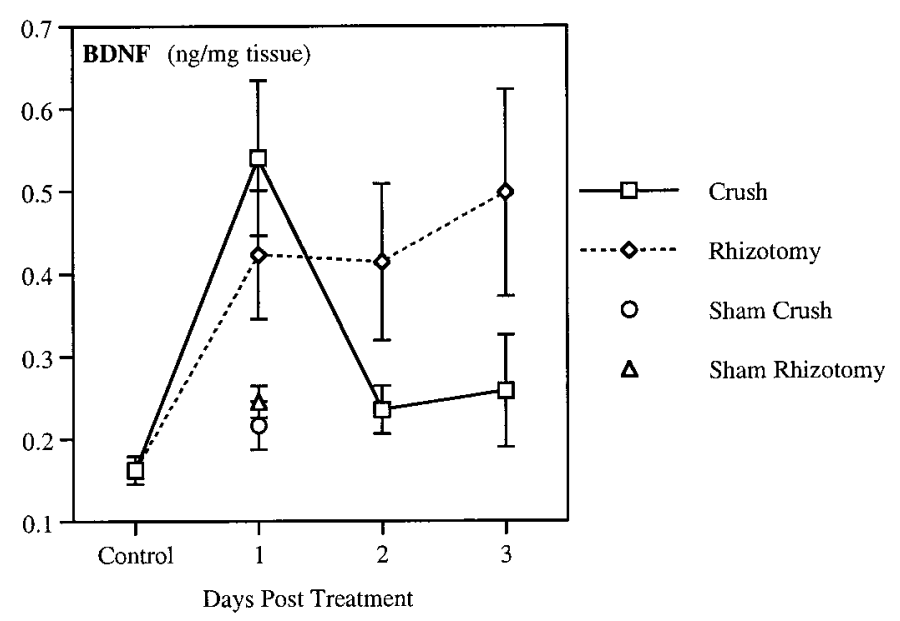

Figure 4. Time course of BDNF anterograde transport after peripheral or central axotomy. Endogenous BDNF was measured in the nerve segment proximal to an $18-20 \mathrm{hr}$ double ligation of the sciatic nerve. Ligations were performed on untreated rats (Control) or 1, 2, and $3 \mathrm{~d}$ after rhizotomy (Rhizotomy) or sciatic crush (Crush). To control for the effects of surgical intervention, BDNF was also measured in ligated nerve after sham crush and sham rhizotomy. Data represent mean \pm SEM of four or five animals.

returned to control levels at 2 and 3 days (Fig. 4). In contrast, the proximal accumulation of BDNF remained elevated up to $3 \mathrm{~d}$ after dorsal rhizotomy. Sham surgeries for the nerve crush and dorsal rhizotomy did not significantly increase the anterograde transport of BDNF (Fig. 4).

\section{Source of anterogradely transported BDNF}

Potential sources of the BDNF proximal to a ligation are DRG sensory neurons, motor neurons, or Schwann cells within the nerve. To resolve this, we used in situ hybridization to localize BDNF mRNA expression before and after neuronal injury. BDNF mRNA was observed in DRG sensory neurons from untreated rats (Fig. 5A), and expression was increased $1 \mathrm{~d}$ after crushing or cutting the sciatic nerve (Fig. 5C,E, respectively). Nerve injury increased the number of neurons in the DRG expressing BDNF mRNA and also elevated the signal from individual neurons. BDNF mRNA expression also increased $1 \mathrm{~d}$ after dorsal rhizotomy but not after sham surgery to the nerve or dorsal root (data not shown). Therefore, damage to the central or peripheral process of DRG neurons upregulates BDNF mRNA in these cells at a time when anterograde transport of BDNF into the peripheral processes is also upregulated.

In contrast to the DRG, BDNF mRNA was not detected in motor neurons in the ventral horn of the spinal cord in normal animals or $1 \mathrm{~d}$ after cutting (Fig. $5 G, H$ ) or crushing (data not shown) the sciatic nerve. To demonstrate the contribution of Schwann cells to the BDNF measured in the proximal segments, we also examined BDNF mRNA expression proximal to the ligations. BDNF mRNA expression, although apparent in Schwann cells, was unchanged 18-20 hr after ligation, with or without previous nerve lesion (Fig. $5 K, J$, respectively). Thus, local synthesis of BDNF by Schwann cells does not contribute to the increased proximal accumulation of BDNF in the nerve. The sense strand showed no hybridization in DRG or nerve (Fig. $5 B, I)$.

In situ hybridization results show that BDNF can be synthesized in nerve. Thus, it is conceivable that BDNF might be taken up by axons from within the nerve at a site proximal to the ligations, and be anterogradely transported. To test this possibility, we determined whether exogenous ${ }^{125}$ I-labeled BDNF injected into the nerve proximal to a ligation could be bound, endocytosed, and anterogradely transported by axonal processes. Retrograde and anterograde transport of exogenous BDNF was investigated in sciatic nerve with or without nerve crush. One day after crushing the nerve distally, a single ligature was placed on the sciatic nerve proximal to the crush, and ${ }^{125}$ I-BDNF was injected $(0.5 \mu$ l volume $) 14-16 \mathrm{~mm}$ proximal or distal to the ligature (diagrams in Fig. 6). Both the ligation and injection were made proximal to the crush site. Approximately $20 \mathrm{hr}$ after the injection, the portion of the nerve between the injection site and ligation was removed and divided into $2 \mathrm{~mm}$ nerve segments for gamma counting. We have shown that, $18-20 \mathrm{hr}$ after injection into the sciatic nerve, $>90 \%$ of the ${ }^{125}$ I-BDNF remains intact $(R$. Curtis and P. S. DiStefano, unpublished data). After distal injection, there was build up of ${ }^{125} \mathrm{I}-\mathrm{BDNF}$ at the ligature, demonstrating that axons can take up and retrogradely transport BDNF present in the nerve as expected (Fig. 6B). Retrograde accumulation of BDNF was enhanced by previous nerve crush compared to sham surgery. In contrast, there was no buildup of ${ }^{125} \mathrm{I}-\mathrm{BDNF}$ at the ligation site after proximal injection either with previous nerve crush or sham surgery (Fig. $6 A$ ), supporting the conclusion that BDNF produced within the nerve is not the source of anterogradely transported BDNF.

From these results, it is likely that DRG sensory neurons are the major contributing source of anterogradely transported BDNF both before and after injury. To confirm this, we measured BDNF protein levels by ELISA in the DRG before and after neuronal injury. BDNF levels in the ipsilateral DRG were increased approximately twofold to threefold $1 \mathrm{~d}$ after sciatic nerve crush or rhizotomy (Fig. 7; two-way ANOVA, $\mathrm{F}_{(1,27)}=$ 14.368; $p=0.0008)$. BDNF levels were not increased in the contralateral DRG by any manipulations. These data suggest that BDNF mRNA is translated into protein, but quantitative comparisons are difficult because of the likely anterograde and retrograde trafficking of BDNF through the ganglion.

\section{DISCUSSION}

The target-derived model of neurotrophin action has recently been supplemented by the concept that neurons themselves express neurotrophins (Ernfors et al., 1990; Schecterson and Bothwell, 1992). Neuronal neurotrophins may act in a paracrine or autocrine manner on neurons within the same ganglion or nucleus (Acheson et al., 1995; Wetmore and Olson, 1995). The demonstration of anterograde transport further alters this model, suggesting neurotrophic actions on distant neurons or other target tissues. We have demonstrated increased anterograde transport of BDNF in response to neuronal injury, thus implicating $\mathrm{BDNF}$ in the process of nerve regeneration.

\section{Source of BDNF}

We have presented several lines of evidence that BDNF is anterogradely transported in the sciatic nerve and that this transport is increased after nerve injury. As expected of an anterogradely transported protein, BDNF accumulated proximal to a double ligation of the sciatic nerve over 18-20 hr. Moreover, the distribution of BDNF in axons overlapped with the anterogradely transported neuropeptides SP and CGRP. A sensitive two-site ELISA confirmed the immunohistochemical results, showing that BDNF protein levels at the proximal ligature increased 30 -fold 

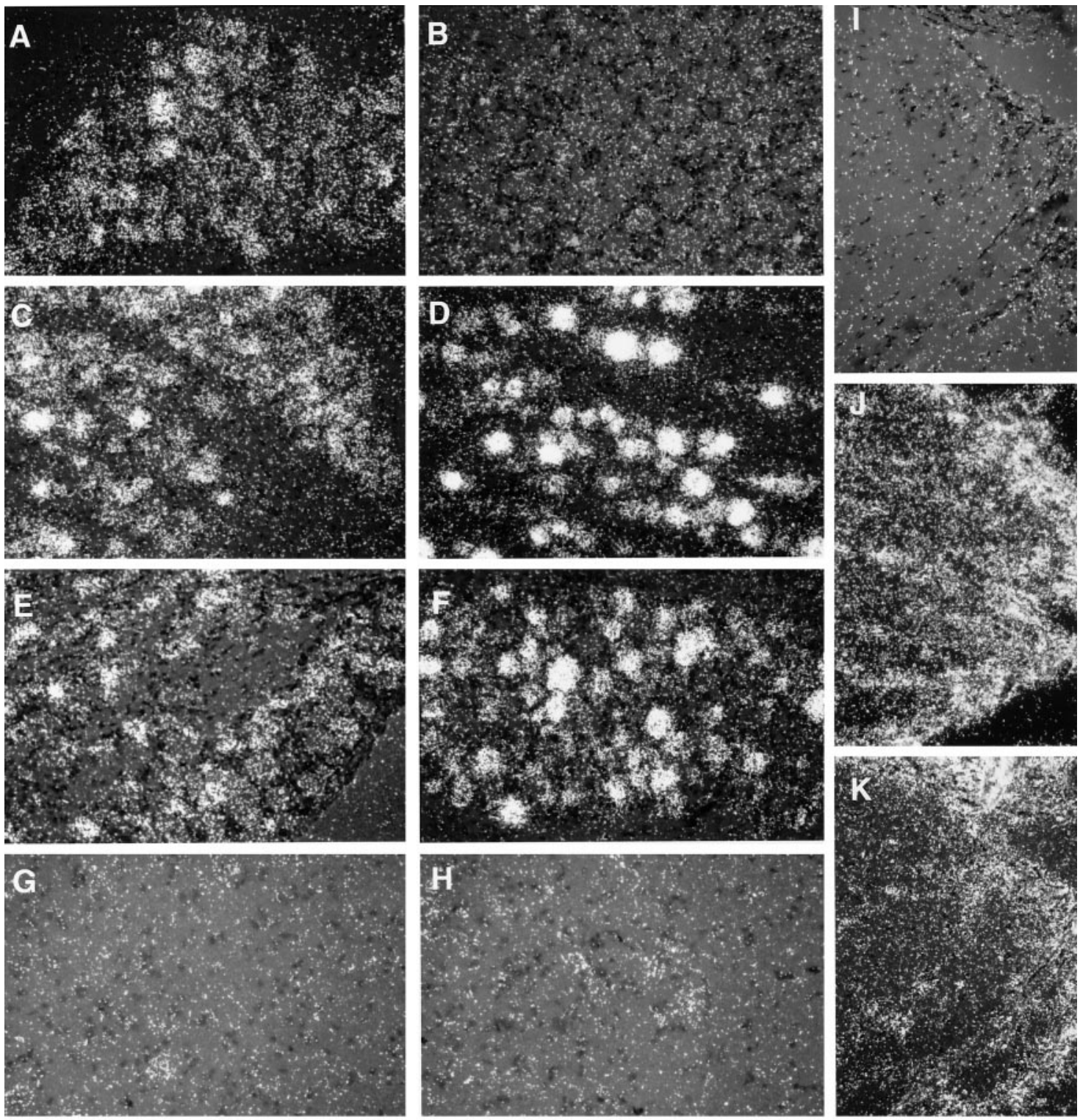

Figure 5. BDNF in situ hybridization in L5 DRG, spinal cord, and sciatic nerve proximal to a ligation. $A$, Untreated DRG; $B$, sense strand hybridization control of ipsilateral DRG $1 \mathrm{~d}$ after sciatic crush; $C, D$, ipsilateral and contralateral DRG, respectively, $1 \mathrm{~d}$ after sciatic crush; $E$, $F$, ipsilateral and contralateral DRG, respectively, $1 \mathrm{~d}$ after cutting the sciatic nerve; $G, H$, ipsilateral and contralateral ventral horn, respectively, $1 \mathrm{~d}$ after cutting the sciatic nerve; $I$, sense strand hybridization control of nerve segment proximal to an $18-20 \mathrm{hr}$ double ligation; $J$, proximal nerve segment removed immediately after placement of a double ligation; $K$, proximal nerve segment removed $18-20 \mathrm{hr}$ after ligation of the sciatic nerve $1 \mathrm{~d}$ after sciatic nerve crush distal to the ligation site. Scale bar, $100 \mu \mathrm{m}$.

over baseline during the 18-20 hr ligation period. In situ hybridization showed that BDNF mRNA expression was not changed in this region after $20 \mathrm{hr}$ of ligation, arguing against local production of BDNF by Schwann cells as the source of the accumulated BDNF. This is consistent with previous results that BDNF mRNA expression is not increased until 3-7 d after sciatic nerve injury in adult rats (Meyer et al., 1992; Funakoshi et al., 1993). Finally, BDNF anterograde transport was increased after axotomy of DRG neurons by either sciatic nerve crush or dorsal rhizotomy, which is correlated with increased expression of BDNF mRNA and protein in the DRG neurons (see below).

There are three potential sources of the anterogradely transported BDNF. First it is possible that BDNF synthesized in peripheral target tissues, and retrogradely transported to the DRG, is anterogradely transported back along the peripheral axons. Although we have not been able to exclude this possibility, peripheral administration of a BDNF antisera that blocks retrograde BDNF transport does not block the anterograde transport of BDNF (Zhou and Rush, 1996). Second, it is conceivable that BDNF released by Schwann cells in the nerve is taken up into axons and anterogradely transported. We have shown that exogenous ${ }^{125}$ I-BDNF injected into the sciatic nerve proximal to a ligature did not result in accumulation, suggesting that BDNF in the nerve cannot be taken up and transported anterogradely. The third possibility, which we favor, is that DRG neurons are the source of the anterogradely transported BDNF. In situ hybrid- 
A

Figure 6. Exogenous ${ }^{125} \mathrm{I}$ BDNF injected into the sciatic nerve is retrogradely but not anterogradely transported. The nerve was crushed (shaded bars) or sham crushed (solid bars) 24 hr earlier. ${ }^{125}$ I-BDNF injections were made 14-16 mm proximal ( $A$, anterograde transport) or distal ( $B$, retrograde transport) to a single ligation of the sciatic nerve, as indicated. The nerve was removed $\sim 20 \mathrm{hr}$ after injection, cut into $2 \mathrm{~mm}$ nerve segments, and counted in a gamma counter. Data represent mean counts per minute $(C P M) \pm$ SEM of three animals. Note that the $y$-axis has been truncated at 28,000 CPM to illustrate ${ }^{125}$ I BDNF levels at the ligation site. ${ }^{125} \mathrm{I}$ BDNF levels at the injection site were $100,000-150,000$ CPM. ${ }^{*} p<$ $0.05 ; * * p<0.01$ versus the adjacent segment 4 $\mathrm{mm}$ from the ligature.

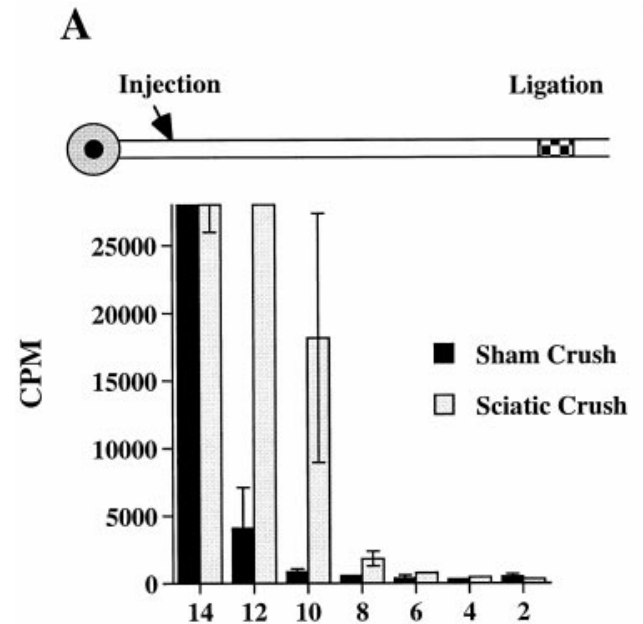

B

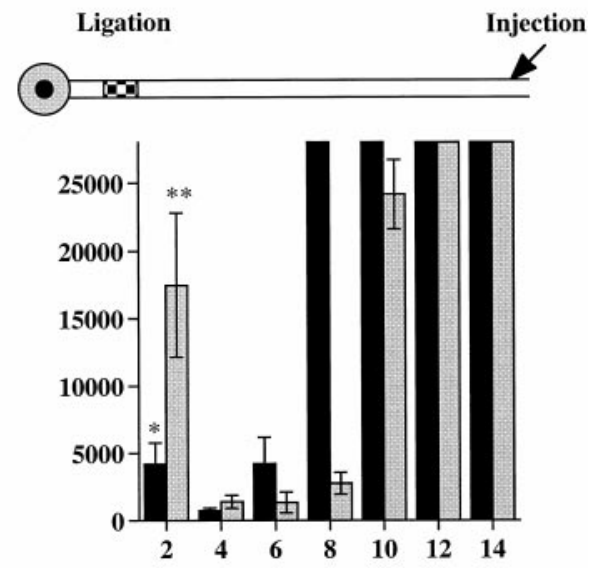

Distance from ligation (mm)

ization showed relatively high BDNF mRNA levels in a defined subset of DRG neurons (Ernfors et al., 1990; Schecterson and Bothwell, 1992; Kashiba et al., 1997). Injury to either the central or peripheral process of sensory neurons caused an upregulation of BDNF mRNA in these cells within $1 \mathrm{~d}$. Additionally, we have shown increased levels of BDNF protein by ELISA, consistent with increased BDNF mRNA in DRG $1 \mathrm{~d}$ after sciatic nerve injury (Sebert and Shooter, 1993). This elevated BDNF expression corresponds with increased BDNF anterograde transport in the sciatic nerve. Preliminary reports suggest that, in addition to trkA-positive sensory neurons, trkB- and trkC-positive sensory neurons also express BDNF mRNA after nerve injury (Averill et al., 1997). In agreement with previous reports (Ernfors et al., 1990), we found that normal, and also axotomized, spinal cord motor neurons did not express detectable BDNF mRNA by in situ hybridization. However, others have reported that BDNF mRNA is increased in axotomized rat facial motor neurons $1 \mathrm{~d}$ after axotomy (Kobayashi et al., 1996), which may reflect an inherent difference between spinal and brainstem motor neurons.

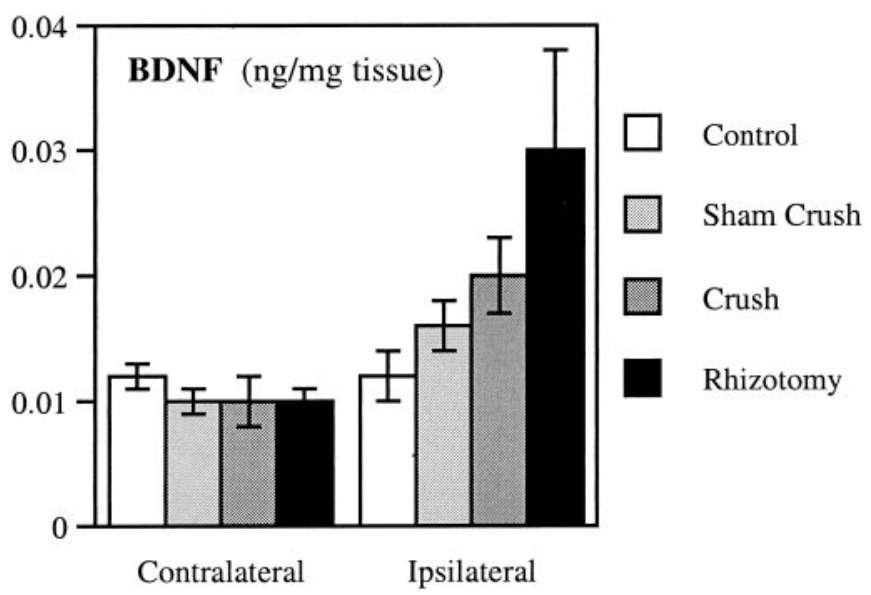

Figure 7. BDNF levels are increased after axotomy. Endogenous BDNF was measured by ELISA in the right DRG (Ipsilateral) and left DRG (Contralateral) from untreated animals $(\mathrm{Control})$ or $1 \mathrm{~d}$ after rhizotomy (Rhizotomy), sciatic crush (Crush), or sham crush (Sham Crush). Values represent the mean \pm SEM of three to five animals and are representative of two experiments in the case of crush and sham crush.
Anterograde transport in the sciatic nerve appears to be specific for BDNF among the neurotrophins studied. NGF accumulated only in the distal nerve segment, indicating only retrograde transport of endogenous NGF, as expected from the lack of NGF mRNA in the adult rat spinal cord and DRG neurons (Korsching and Thoenen, 1985; Kashiba et al., 1997). NT-3 levels did not specifically increase in any nerve segments after double ligation, consistent with the lack of NT-3 mRNA in the adult rat DRG and spinal cord (Ernfors et al., 1990; Kashiba et al., 1997) (J. R. Tonra and P. S. DiStefano, unpublished data). The increased NT-3 protein levels after ligation compared with baseline may represent local production, although NT-3 mRNA expression has been reported to decrease by $\sim 50 \% 1 \mathrm{~d}$ after sciatic nerve transection (Funakoshi et al., 1993).

\section{Targets of BDNF action}

There are three possible targets for anterogradely transported BDNF in the sciatic nerve: peripheral target tissues, Schwann cells in the nerve, and peripherally projecting neurons. BDNF may be released at the axon terminals in the skin and muscle, serving as a neurotransmitter on responsive peripheral target tissues. Several observations suggest a role for BDNF in neurotransmission. In culture, BDNF modulates the excitability of developing neuromuscular synapses (Lohof et al., 1993) and regulates postsynaptic activity in hippocampal neurons (Kang and Schuman, 1995; Levine et al., 1995) via trkB receptors localized in hippocampal postsynaptic densities (Wu et al., 1996). BDNF is present in the synaptosomal fraction isolated from adult rat cortex (Fawcett et al., 1997) and shows activity-dependent release (Androutsellis-Theotokis et al., 1996). In spinal cord, BDNF is localized in vesicles within axon terminals in the superficial dorsal horn (Michael et al., 1997). BDNF immunoreactivity in dorsal horn can be abolished by rhizotomy (Zhou and Rush, 1996) (Tonra and DiStefano, unpublished observations), suggesting that it arises from primary nociceptive neurons in the DRG and, therefore, may be involved in responses to painful stimuli.

The targets of anterogradely transported BDNF are likely to change in pathological states, such as peripheral nerve trauma. A role for BDNF after nerve injury is supported by the increased BDNF expression in injured sensory neurons and accumulation in the tip of the proximal nerve stump. It is possible that anterogradely transported BDNF may be released at the site of axon 
damage to support peripheral neurons that have lost targetderived trophic factors. The calculated concentration of BDNF proximal to a ligature $\left(\sim 2 \times 10^{-9} \mathrm{M}\right)$ is likely to activate receptors for BDNF $\left(K_{\mathrm{d}}, 10^{-10}-10^{-11} \mathrm{M}\right)$ (Chao, 1994; Chao and Hempstead, 1995). Acheson et al. (1995) have shown a paracrine and autocrine requirement for BDNF in the survival of adult sensory neurons in vitro, so BDNF released from damaged axons may prevent the axotomy-induced death of a population of DRG neurons. BDNF released from sensory neurons may also provide trophic support to damaged motor neurons (DiStefano et al., 1992; Yan et al., 1992; Friedman et al., 1995) that express the catalytic isoform of trkB (Koliatsos et al., 1993). Because levels of anterogradely transported BDNF return to normal by $2 \mathrm{~d}$, the regenerating axons may find an alternative source of BDNF in Schwann cells in the distal stump, which show increased synthesis of BDNF at later times after nerve lesion (Meyer et al., 1992; Funakoshi et al., 1993).

A role for BDNF in the response to nerve injury is further suggested by increased receptor-mediated retrograde transport of exogenous ${ }^{125} \mathrm{I}-\mathrm{BDNF}$ to sensory and motor neurons $1 \mathrm{~d}$ after sciatic nerve crush or dorsal rhizotomy (DiStefano and Curtis, 1994) (R. Curtis, J. R. Tonra and P. S. DiStefano, unpublished observation). This is thought to be mediated by a generalized increase in anterograde and retrograde transport capacity of injured neurons, possibly related to increased expression of axonal transport motor proteins (Su et al., 1997). Increased synthesis and anterograde transport of BDNF by sensory neurons after nerve injury could be part of a coordinated program to enhance the survival of axotomized neurons. This may be a general response of sensory neurons to injury, because increased BDNF anterograde transport also occurs after rhizotomy.

Anterogradely transported BDNF may also aid in nerve regeneration. Schwann cells increase their expression of low-affinity neurotrophin receptor (LNR) and a truncated noncatalytic form of trkB after nerve injury (Funakoshi et al., 1993). Anterogradely transported BDNF released by damaged neurons may bind to these receptors expressed on Schwann cells and serve as a localized source of trophic support for regenerating neurons or guide axonal elongation, as proposed previously for NGF (Johnson et al., 1988; Frisén et al., 1993). BDNF released in nerve may also act on Schwann cells expressing LNR after nerve injury. NGF, BDNF, and NT-3 all signal through this receptor via the sphingomyelin-ceramide pathway (Dobrowsky et al., 1995). Because LNR signaling through the ceramide pathway promotes cell death (Rabizadeh et al., 1993; Casaccia-Bonnefil et al., 1996), axonal BDNF may help control Schwann cell numbers after peripheral nerve injury. BDNF released from axons may also regulate Schwann cell migration after nerve injury, an effect induced by NGF that can be inhibited by antibodies to LNR (Anton et al., 1994).

In conclusion, BDNF anterograde transport by sensory neurons is dramatically increased after damage to the peripheral or central axons of sensory neurons. The specificity of this effect for BDNF anterograde transport suggests an important role for this neurotrophin in the functioning of the peripheral nervous system and the response to nerve injury.

\section{REFERENCES}

Acheson A, Conover JC, Fandl JP, DeChiara TM, Russell M, Thadani A, Squinto SP, Yancopoulos GD, Lindsay RM (1995) A BDNF autocrine loop in adult sensory neurons prevents cell death. Nature 374:450-453. Altar CA, Cai N, Bliven T, Juhasz M, Conner JM, Acheson A, Lindsay
RM, Wiegand SJ (1997) Anterograde transport of brain-derived neurotrophic factor and its role in the brain. Nature 389:856-860.

Anderson KD, Alderson RF, Altar CA, DiStefano PS, Corcoran TL, Lindsay RM, Wiegand SJ (1995) Differential distribution of exogenous BDNF, NGF, and NT-3 in the brain corresponds to the relative abundance and distribution of high-affinity and low-affinity neurotrophins receptors. J Comp Neurol 357:296-317.

Androutsellis-Theotokis A, McCormack WJ, Bradford HF, Stern GM, Pliego-Rivero FB (1996) The depolarization-induced release of ${ }^{125} \mathrm{I}$ BDNF from brain tissue. Brain Res 743:40-48.

Anton ES, Weskamp G, Reichardt LF, Matthew WD (1994) Nerve growth factor and its low-affinity receptor promote Schwann cell migration. Proc Natl Acad Sci USA 91:2795-2799.

Averill S, Michael GJ, Shortland PJ, Priestley JV (1997) BDNF increases in large diameter dorsal root ganglion cells and in their central projections following peripheral axotomy. Soc Neurosci Abstr 23:134.8.

Barbacid M (1994) The trk family of neurotrophin receptors. J Neurobiol 25:1386-1403.

Ben-Jonathan N, Maxson RE, Ochs S (1978) Fast axoplasmic transport of noradrenaline and dopamine in mammalian peripheral nerve. J Physiol (Lond) 281:315-324.

Bianchi LM, Conover JC, Fritzsch B, DeChiara T, Lindsay RM, Yancopoulos GD (1996) Degeneration of vestibular neurons in late embryogenesis of both heterozygous and homozygous BDNF null mutant mice. Development 122:1965-1973.

Casaccia-Bonnefil P, Carter BD, Dobrowsky RT, Chao MV (1996) Death of oligodendrocytes mediated by the interaction of nerve growth factor with its receptor p75. Nature 383:716-719.

Chao MV (1994) The p75 neurotrophin receptor. J Neurobiol 25:1373-1385.

Chao MV, Hempstead BL (1995) p75 and Trk: a two-receptor system. Trends Neurosci 18:321-326.

Conner JM, Lauterborn JC, Yan Q, Gall CM, Varon S (1997) Distribution of brain-derived neurotrophic factor (BDNF) protein and mRNA in the normal adult rat CNS: evidence for anterograde axonal transport. J Neurosci 17:2295-2313.

Curtis R, DiStefano PS (1994) Neurotrophic factors, retrograde axonal transport and cell signalling. Trends Cell Biol 4:383-386.

Curtis R, Adryan KM, Stark JL, Park JS, Compton DL, Weskamp G, Huber LJ, Chao MV, Jaenisch R, Lee KF, Lindsay RM, DiStefano PS (1995) Differential role of the low affinity neurotrophin receptor (p75) in retrograde axonal transport of the neurotrophins. Neuron 14:1201-1211.

DiStefano PS, Curtis R (1994) Receptor mediated retrograde axonal transport of neurotrophic factors is increased after peripheral nerve injury. Prog Brain Res 103:35-42.

DiStefano PS, Friedman B, Radziejewski C, Alexander C, Boland P, Schick CM, Lindsay RM, Wiegand SJ (1992) The neurotrophins BDNF, NT-3 and NGF display distinct patterns of retrograde axonal transport in peripheral and central neurons. Neuron 8:983-993.

Dobrowsky RT, Jenkins GM, Hannun YA (1995) Neurotrophins induce sphingomyelin hydrolysis. Modulation by co-expression of p75NTR with Trk receptors. J Biol Chem 270:22135-22142.

Dumoulin FL, Raivich G, Streit WJ, Kreutzberg GW (1991) Differential regulation of calcitonin gene-related peptide (CGRP) in regenerating rat facial nucleus and dorsal root ganglion. Eur J Neurosci 3:338-342.

Ernfors P, Wetmore C, Olson L, Persson H (1990) Identification of cells in rat brain and peripheral tissues expressing mRNA for members of the nerve growth factor family. Neuron 5:511-526.

Fawcett JP, Aloyz R, McLean JH, Pareek S, Miller FD, McPherson PS, Murphy RA (1997) Detection of brain-derived neurotrophic factor in a vesicular fraction of brain synaptosomes. J Biol Chem 272:8837-8840.

Friedman B, Scherer SS, Rudge JS, Helgren M, Morissey D, McClain J, Wang D-Y, Wiegand SJ, Furth ME, Lindsay RM, Ip NY (1992) Regulation of ciliary neurotrophic factor expression in myelin-related Schwann cells in vivo. Neuron 9:295-305.

Friedman B, Kleinfeld D, Ip NY, Verge VMK, Moulton R, Boland P, Zlotchenko E, Lindsay RM, Liu L (1995) BDNF and NT-4/5 exert neurotrophic influences on injured adult spinal motor neurons. J Neurosci 15:1044-1056.

Frisén J, Verge VMK, Fried K, Risling M, Persson H, Trotter J, Hökfelt T, Lindholm D (1993) Characterization of glial trkB receptors: differential response to injury in the central and peripheral nervous system. Proc Natl Acad Sci USA 90:4971-4975.

Funakoshi H, Frisén J, Barbany G, Timmusk T, Zachrisson O, Verge 
VMK, Persson H (1993) Differential expression of mRNAs for neurotrophins and their receptors after axotomy of the sciatic nerve. J Cell Biol 123:455-465.

Henderson CE, Camu W, Mettling C, Gouin A, Poulsen K, Karihaloo M, Rullamas J, Evans T, McMahon SB, Armanini MP (1993) Neurotrophins promote motor neuron survival and are present in embryonic limb bud. Nature 363:266-270.

Ishida-Yamamoto A, Senba E, Tohyama M (1989) Distribution and fine structure of calcitonin gene-related peptide-like immunoreactive nerve fibers in the rat skin. Brain Res 491:93-101.

Jessell T, Tsunoo A, Kanazawa I, Otsuka M (1979) Substance P: depletion in the dorsal horn of rat spinal cord after section of the peripheral processes of primary sensory neurons. Brain Res 168:247-259.

Johnson Jr EM, Taniuchi M, Clark HB, Springer JE, Koh S, Tayrien MW, Loy R (1987) Demonstration of the retrograde transport of nerve growth factor receptor in the peripheral and CNS. J Neurosci 7:923-929.

Johnson Jr EM, Taniuchi M, DiStefano PS (1988) Expression and possible function of nerve growth factor receptors on Schwann cells. Trends Neurosci 11:299-304.

Johnson F, Hohmann SE, DiStefano PS, Bottjer SW (1997) Neurotrophins suppress apoptosis induced by deafferentation of an avian motorcortical region. J Neurosci 17:2101-2111.

Kang H, Schuman EM (1995) Long-lasting neurotrophin-induced enhancement of synaptic transmission in the adult hippocampus. Science 267:1658-1662.

Kashiba H, Ueda Y, Ueyama T, Nemoto K, Senba E (1997) Relationship between BDNF- and trk-expressing neurones in rat dorsal root ganglion: an analysis by in situ hybridization. NeuroReport 8:1229-1234.

Kobayashi NR, Bedard AM, Hincke MT, Tetzlaff W (1996) Increased expression of BDNF and trkB mRNA in rat facial motoneurons after axotomy. Eur J Neurosci 8:1018-1029.

Koliatsos VE, Clatterbuck RE, Winslow JW, Cayoutte MH, Price DL (1993) Evidence that brain-derived neurotrophic factor is a trophic factor for motor neurons in vivo. Neuron 10:359-367.

Korsching S, Thoenen H (1985) Nerve growth factor supply for sensory neurons: site of origin and competition with the sympathetic nervous system. Neurosci Lett 54:201-205.

Kruger L, Sampogna SL, Rodin BE, Clague J, Brecha N, Yeh Y (1985) Thin-fiber cutaneous innervation and its intraepidermal contribution studied by labeling methods and neurotoxin treatment in rats. Somatosens Res 2:335-356.

Levine ES, Dreyfus CF, Black IB, Plummer MR (1995) Brain-derived neurotrophic factor rapidly enhances synaptic transmission in hippocampal neurons via postsynaptic tyrosine kinase receptors. Proc Natl Acad Sci USA 92:8074-8077.

Lohof AM, Ip NY, Poo MM (1993) Potentiation of developing neuromuscular synapses by the neurotrophins NT-3 and BDNF. Nature 363:350-353.

Maisonpierre PC, Le Beau MM, Espinosa III R, Ip NY, Belluscio L, De La Monte SM, Squinto S, Furth ME, Yancopoulos GD (1991) Human and rat brain-derived neurotrophic factor and neurotrophin-3: gene structures, distributions, and chromosomal localizations. Genomics 10:558-568.
Meyer M, Matsuoka I, Wetmore C, Olson L, Thoenen H (1992) Enhanced synthesis of brain-derived neurotrophic factor in the lesioned peripheral nerve: different mechanisms are responsible for the regulation of BDNF and NGF mRNA. J Cell Biol 119:45-54.

Michael GJ, Averill S, Nitkunan A, Rattray M, Bennett DLH, Yan Q, Priestley JV (1997) Nerve growth factor treatment increases brainderived neurotrophic factor selectively in tyrosine kinase A-expressing dorsal root ganglion cells and in their central terminations within the spinal cord. J Neurosci 17:8476-8490.

Palmatier MA, Hartman BK, Johnson Jr EM (1984) Demonstration of retrogradely transported endogenous nerve growth factor in axons of sympathetic neurons. J Neurosci 4:751-756.

Rabizadeh S, Oh J, Zhong LT, Yang J, Bitler CM, Butcher LL, Bredesen DE (1993) Induction of apoptosis by the low-affinity NGF receptor. Science 261:345-348.

Radka SF, Holst PA, Fritsche M, Altar CA (1996) Presence of brainderived neurotrophic factor in brain and human and rat but not mouse serum detected by a sensitive and specific immunoassay. Brain Res 709:122-130.

Ranish N, Ochs S (1972) Fast axoplasmic transport of acetylcholinesterase in mammalian nerve fibers. J Neurochem 19:2641-2649.

Schecterson LC, Bothwell M (1992) Novel roles for neurotrophins are suggested by BDNF and NT-3 mRNA expression in developing neurons. Neuron 9:449-463.

Sebert ME, Shooter EM (1993) Expression of mRNA for neurotrophic factors and their receptors in the rat dorsal root ganglion and sciatic nerve following nerve injury. J Neurosci Res 36:357-367.

Snider WD (1994) Functions of the neurotrophins during nervous system development: what the knockouts are teaching us. Cell 77:627-638

Su QN, Namikawa K, Toki H, Kiyama H (1997) Differential display reveals transcriptional upregulation of the motor molecules for both anterograde and retrograde axonal transport during nerve regeneration. Eur J Neurosci 9:1542-1547.

Swett JE, Torigoe Y, Elie VR, Bourassa CM, Miller PG (1991) Sensory neurons of the rat sciatic nerve. Exp Neurol 114:82-103.

von Bartheld CS, Byers MR, Williams R, Bothwell M (1996) Anterograde transport of neurotrophins and axodendritic transfer in the developing visual system. Nature 379:830-833.

Wetmore C, Olson L (1995) Neuronal and nonneuronal expression of neurotrophins and their receptors in sensory and sympathetic ganglia suggest new intercellular trophic interactions. J Comp Neurol 353:143-159.

Wong V, Kessler JA (1987) Solubilization of a membrane factor that stimulates levels of substance $\mathrm{P}$ and choline acetyltransferase in sympathetic neurons. Proc Natl Acad Sci USA 84:8726-8729.

Wu K, Xu JL, Suen PC, Levine ES, Lin SY, Huang YY, Mount HTJ, Black IB (1996) Functional trkB neurotophin receptors are intrinsic components of the adult brain postsynaptic density. Mol Brain Res 43:286-290

Yan Q, Elliott J, Snider WD (1992) Brain-derived neurotrophic factor rescues spinal motor neurons from axotomy-induced cell death. Nature 360:753-755.

Zhou XF, Rush RA (1996) Endogenous brain-derived neurotrophic factor is anterogradely transported in primary sensory neurons. Neuroscience 74:945-953. 